Bull. Fac. Agric., Cairo Univ., 67: 153-165(2016).

\title{
EFFECT OF SOWING DATE AND N FERTILIZATION ON YIELD AND ITS COMPONENTS OF TWO HULL-LESS BARLEY CULTIVARS
}

(Received: 24.4.2016)

\author{
By \\ H.A. Ashmawy, A.A. Badawy and H. E. A. El-Nady \\ Barley Research Department, Field Crops Research Institute, \\ Agricultural Research Center, Giza, Egypt.
}

\begin{abstract}
Among the cultural practices, sowing date and fertilizer application are some of the limiting factors to achieve production potential of the crop. A two year field experiment was conducted at El-Kharga district in the New Valley during 2012/2013 and 2013/2014 seasons, respectively, to investigate the effect of two sowing dates (Nov, 20 and Dec. 20) and four N

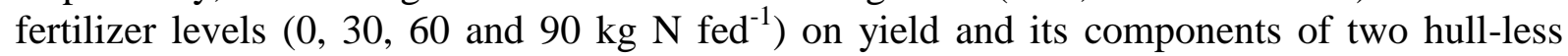
barley cultivars (Giza 130 and Giza 135). Results showed that days to heading, plant height, days to maturity, yield components (spike length, number of grain spike ${ }^{-1}$, spike kernel weight and 1000-kernel weight), and grain yield of barley were significantly affected by sowing date. Giza 130 sown on 20 Nov. produced the highest grain yield compared with sowing on 20 Dec. irrespective of the fertilizer used. Also, sowing at 20 Nov. gave the highest number of kernels spike $^{-1}$, 1000-kernel weight and biological yield with Giza 130. Grain yield and yield components of barley were also affected by $\mathrm{N}$ fertilizer levels. Days to heading, days to maturity, 1000-kernel weight, biological yield and grain yield increased with increasing nitrogen application level up to $90 \mathrm{~kg} \mathrm{~N} \mathrm{fed}^{-1}$. The interaction between sowing date and cultivar had a significant effect on all the studied traits except for days to maturity. However, the interaction effect of sowing date and $\mathrm{N}$ fertilizer indicated that the highest grain yield was obtained from the treatment of 20 Nov. sowing with $90 \mathrm{~kg} \mathrm{fed}^{-1} \mathrm{~N}$. Also, the interaction among sowing dates, cultivar and nitrogen fertilizer was significant for all traits, except for days of maturity. It can be concluded that $20 \mathrm{Nov}$. sowing date with $90 \mathrm{Kg} \mathrm{N} \mathrm{fed}^{-1}$ might be sustainable approach for achieving the highest production of Giza 130 under the New Valley conditions in Upper Egypt.
\end{abstract}

Key words: Hordeum vulgare L, sowing date, $N$ fertilizer levels, grain yield, biological yield.

\section{INTRODUCTION}

Barley (Hordeum vulgare L.) is the major cereal crop in many dry areas of the world and is vital for the livelihoods of many farmers. Barley is an annual cereal crop grown in environments ranging from the desert of the Middle East to the high elevation of Himalayas (Hayes et al., 2003). It is usually used as food for humans and feed for animals and poultry. The variety plays an important role for producing better yield and seed quality of barley. Different varieties respond differently for their genotypic characters, input requirement, growth process and the prevailing environment during growing season (Yesmin et al., 2014). Sowing date and fertilizer rate control the yield. Effect of sowing time and fertilizer levels on the yield of barley was tested under rainfed condition. The differences in yield of early and late sown crops may be due to favorable temperatures at different growth stages, which may increase photosynthetic rate. Heat stress during and after anthesis growth stages mainly affects assimilates availability, 
New Valley conditions. Nile alley and Red Sea Regional Program. ICARDA. " $10^{\text {th }}$ Annual coordination meeting. Egypt, ARC, Cairo 6-11 September 1998" pp: 151-155.

Refay Y.A. (2011). Yield and yield component parameters of bread wheat genotypes as affected by sowing date. Middle-East J. Sci. Res., 7(4): 484-489.

Said A., Gul H., Saeed B., Haleema B., Badshah N. and Parveen L. (2012). Response of wheat to different planting dates and seeding rates for yield and yield components. Agron. J. Agric. Biol. Sci., 7(2): 138-140.

Shahnaj Yesmin, Akhtar M. and Hossain B. (2014). Yield and seed quality of barley (Hordeum vulgare L.) as affected by variety, nitrogen levels and harvesting time. Intl. J. Agri. Crop Sci.,7(3): 147153.

Steel R. G. D. and Torrie D.S. (1980). Principal and procedures of statistics, a bioemetrical approach. McGraw-Hill Book Company new York, second Edit.

Towfelis M. B. (1989). The influence of some agricultural treatments on growth yield and its components of barley. M.Sc. Thesis, Fac. Agric., Minia Univ., Egypt,

Turk M. A., Tawala A. M., Samarah N. and Allataifeh N. (2003). The response of awnless six row barley to nitrogen fertilizer application and weed control methods in the absence of moisture stress. Pak. J. Agron., 2:101-108.

$$
\begin{aligned}
& \text { تأثير مواعيد الزراعة والتسميد النتروجينى على المحصول ومكوناته لصنفين من الثعير العارى } \\
& \text { حسن عبد الجليل عشماوى ـ عبد العاطى احمد بدوى ـ هانم السيد احمد النادى } \\
& \text { قسم بحوث الثعير معهد بحوث المحاصيل الحقلية ـ مركز البحوث الزر اعيةـ الجيزة ـ مصر }
\end{aligned}
$$

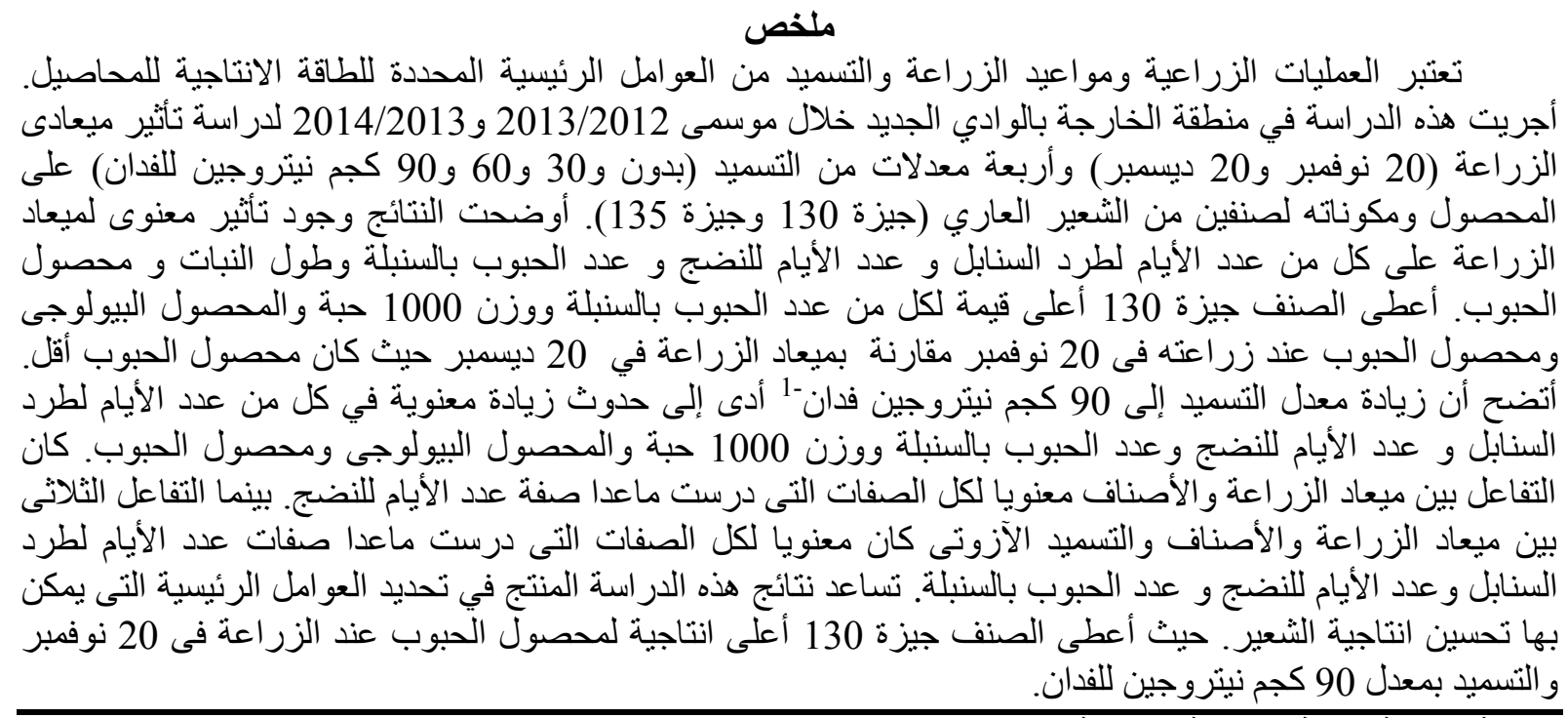

المجلة العلمية لكلية الزراعة -جامعة القاهرة ـ المجلد (67) العدد الثانى (ابريل 2016 ) : 153- 
translocation of photo-synthates to the grain and starch synthesis and deposition in the developing grain. (Modhej 2011). Among the nutrient elements, nitrogen plays a vital role in growth and development of the crop and also affects seed quality at its optimum level, although judicious dose of nitrogen elevates the yield and quality of barley seeds. The optimum dose of nitrogen varies from location to location (Yesmin et al., 2014). Hefni (1976) stated that grain yield of barley increased significantly as nitrogen rates increased up to $50 \mathrm{~kg} \mathrm{~N}^{-1} \mathrm{f}^{-1}$ in Egypt,. Also, Turk et al., (2003) indicated that the highest grain yield of barley under $120 \mathrm{Kg} \mathrm{N}$ ha $^{-1}$ among $\mathrm{N}$ rates owing to highest number of spikes $\mathrm{m}^{-1}(537.5)$ and the number of grains spike ${ }^{-1}$ (56.3) of barley than the control. Misra et al., (1980) stated that increasing $\mathrm{N}$ up to the level of $60 \mathrm{~kg} \mathrm{~N} \mathrm{ha}^{-1}$ resulted in a significant increase in straw yield of barley. Towfelis (1989) found that increasing nitrogen levels up to $60 \mathrm{~kg} \mathrm{fed}^{-1}$ led to progressive increase in the number of spikes $\mathrm{m}^{-2}$, grain yield and straw yield, while harvest index decreased with increasing $\mathrm{N}$ application. Orabi et al. (1998) studied the effect of nitrogen fertilization on barley under the New Valley conditions. They pointed out that increasing nitrogen level up to $178.5 \mathrm{kgN} \mathrm{ha}^{-1}$ caused significant increase in plant height, 1000 kernel weight, biological yield, straw yield and grain yield. Treated barley plants by $178.5 \mathrm{~kg} \mathrm{~N}^{-1}$ with weekly irrigation was considered the best combination for barley production under the New Valley conditions. Many research workers indicated that early planting increased the yield attributes and yield of different crops than late planting in different climatic conditions (Abdur et al., 2010). Unfavorable air temperature during grain filling is considered the major factor reducing barley production in Middle and Upper Egypt. Also interesting of barley response to environmental stresses has been increased in recent years because severe losses that result from climate changes and high concentrations of toxic elements (Lewis and Christiansen 1981, and Blum, 1985).
The present study was conducted to determine the optimal sowing date and $\mathrm{N}$ fertilizer application for two hull-less barley cultivars for yield and its components under the New Valley conditions.

\section{MATERIALS AND METHODS}

The present study was carried out at the Experimental Farm of El-Kharga Research Station, the New Valley Governorate, Egypt, during the two successive seasons of 2012/2013 and 2013/2014.

Two sowing dates $\left(20^{\text {th }}\right.$ Nov. and $20^{\text {th }}$ Dec.), four nitrogen fertilizer levels $(0,30$, 60 and $90 \mathrm{Kg} \mathrm{N} \mathrm{fed}{ }^{-1}$ ) and two hull-less barley cultivars (Giza 130 and Giza 135) were used.

The experimental design was a split-split plot in a randomized complete block arrangement with three replications. The main plots were assigned to sowing dates, while the sub plots were assigned to cultivars and sub-sub plots were assigned to nitrogen fertilizer treatments. The plot size (experimental unit) was $4.2 \mathrm{~m}^{2}$ (6 rows x 0.2 $\mathrm{m} \times 3.5 \mathrm{~m})$. Sowing was done by Drill method at the rate of $50 \mathrm{Kg} \mathrm{fed}{ }^{-1}$. Phosphorous fertilizer was applied during seedbed preparation at the rate of $60 \mathrm{Kg}$ $\mathrm{P}_{2} \mathrm{O}_{5} \mathrm{fed}^{-1}$ in the form of super phosphate $\left(\begin{array}{lll}15.5 \% & \mathrm{P}_{2} \mathrm{O}_{5}\end{array}\right)$. Potassium fertilizer was applied at the rate of $24 \mathrm{Kg} \mathrm{K}_{2} \mathrm{O} \mathrm{fed}^{-1}$ in the form of potassium sulphate $\left(48 \% \mathrm{~K}_{2} \mathrm{O}\right)$ in two equal doses, the first dose was applied during seedbed preparation, while the second one was applied at 30 days after sowing. Nitrogen fertilizer was applied in the form of ammonium nitrate $(33.5 \%)$ in three equal doses; the first dose was at sowing and the other two doses were applied at 21 and 45 days after sowing.

The other cultural practices were carried out according to the barley production practices followed at the New Valley, Egypt. The following growth and yield traits were recorded; days to heading, days to physiological maturity, plant height, spike length, number of kernels spike ${ }^{-1}$, spike kernel weight, 1000-kernel weight, biological yield, grain yield, straw yield and 
harvest index. The data were analyzed according to split-split-plot design. Standard analysis of variance using Least Significant Differences (LSD) was performed to estimate the significant differences among treatments (Steel and Torrie, 1980). Representative soil samples were taken from El-Kharga in 2012/13 and 2013/14 seasons before planting and were chemically and mechanically analyzed (Table 1). The average temperature and relative humidity were recorded during the two growing seasons as presented in Table (2). days to heading was $64.7,67.8,70.1$ and 71.2 days in the $1^{\text {st }}$ season and 64.3, 66.8, 69.1 and 70.8 days in the $2^{\text {nd }}$ season with 0 , 30,60 and $90 \mathrm{~kg} \mathrm{~N} \mathrm{fed}^{-1}$, respectively. The increase in the number of days to heading due to nitrogen fertilizer may be attributed to the retarding effect of the nitrogen element on the transition of the growing point from vegetative to floral stage. These results are in harmony with those of Mohamed (2009). Maximum number of days to heading (71.5 and 73.2 days) was from Giza 130 with 90 $\mathrm{kg} \mathrm{N} \mathrm{fed}{ }^{-1}$ fertilizer in both seasons, respectively.

Table (1): Soil chemical and mechanical analyses at El-Kharga, the New Valley Governorate in 2012/013 and 2013/014 seasons.

\begin{tabular}{|c|c|c|c|c|c|c|c|c|c|c|c|}
\hline \multirow{3}{*}{ El-Kharg } & \multirow{2}{*}{\multicolumn{3}{|c|}{$\begin{array}{c}\text { Chemical analysis } \\
\text { ppm } \\
\end{array}$}} & \multicolumn{8}{|c|}{ Mechanical analysis } \\
\hline & & & & \multirow{2}{*}{ pH } & \multirow{2}{*}{$\frac{\text { EC }}{\text { Dsm }^{-1}}$} & \multirow{2}{*}{$\frac{\mathrm{CaCO}_{3}}{\%}$} & \multirow{2}{*}{$\begin{array}{c}\text { Clay } \\
\%\end{array}$} & \multirow{2}{*}{$\begin{array}{c}\text { Silt } \\
\%\end{array}$} & \multirow{2}{*}{$\begin{array}{c}\text { Fine } \\
\text { Sand } \%\end{array}$} & \multirow{2}{*}{$\begin{array}{c}\text { Coarse } \\
\text { Sand \% }\end{array}$} & \multirow{2}{*}{ Texture } \\
\hline & $\mathbf{N}$ & $\mathbf{P}$ & $\mathbf{K}$ & & & & & & & & \\
\hline $\begin{array}{c}1^{\mathrm{st}} \\
\text { season } \\
\end{array}$ & 22.0 & 11.0 & 210 & 7.6 & 1.46 & 2.00 & 18.9 & 10.6 & 70.5 & 23.5 & Sandy loam \\
\hline $\begin{array}{c}2^{\text {sd }} \\
\text { season }\end{array}$ & 20.0 & 10.0 & 200 & 7.7 & 1.55 & 3.80 & 18.0 & 12.5 & 69.5 & 25.0 & Sandy loam \\
\hline
\end{tabular}

Table (2): Means of maximum and minimum temperature and relative humidity at El-Kharga, the New Valley Governorate in 2012/2013 and 013/2014 seasons.

\begin{tabular}{|c|c|c|c|c|c|c|}
\hline \multirow{2}{*}{$\begin{array}{c}\text { Date } \\
\text { Nov: April }\end{array}$} & \multicolumn{7}{|c|}{ El-Kharga } \\
\cline { 2 - 7 } & \multicolumn{7}{|c|}{$2012 / 2013$} & 2013/2014 & RH\% \\
\cline { 2 - 7 } Mean & Max & Min & RH\% & Max & Min & 39.2 \\
\hline
\end{tabular}

\section{RESULTS AND DISCUSSION}

\subsection{Vegetative Growth}

\subsubsection{Days to heading}

Results concerning days to heading are presented in Table (3). Days to heading were significantly $(p \leq 0.05)$ affected by sowing date, cultivar and $\mathrm{N}$ levels in both season and $\mathrm{SxG}$ interaction in the $2^{\text {nd }}$ one Table (3) showed That sowing date on $20^{\text {th }}$ Nov. gave maximum days to heading, while sowing date on $20^{\text {th }}$ Dec. exhibited minimum days to heading. Days to heading varied from 61.0 to 73.3 days at the $1^{\text {st }}$ season and from 55.0 to 74.7 days at the $2^{\text {nd }}$ season. Also, the results revealed that heading for Giza 135 was earlier than Giza 130 across the two seasons. The average number of

\subsubsection{Days to physiological maturity}

Results presented in Table (4) indicated that different sowing dates, cultivars and $\mathrm{N}$ levels had a significant effect on this treat in both seasons, except for sowing date in the $2^{\text {nd }}$ season.

Days to maturity varied from 95.0 to 113.3 the days at the $1^{\text {st }}$ season and from 94.3 to 112.0 days at the $2^{\text {nd }}$ season. Also, the results revealed that maturity for Giza 135 was earlier than Giza 130 across the two seasons. The average number of days to maturity was 97.3, 102.8, 105.8 and 110.0 days in the $1^{\text {st }}$ season and 100.0, 103.8, 106.2 and 108.7 days in the $2^{\text {nd }}$ season with $0,30,60$ and $90 \mathrm{~kg} \mathrm{~N}^{-1} \mathrm{fed}^{-1}$, respectively. Application of $90 \mathrm{~kg} \mathrm{~N}$ fed $^{-1}$ gave the highest number of days to maturity (110.0 
Table (3): Mean number of days to heading as influenced by sowing date, nitrogen level, cultivars and their interactions in both seasons.

\begin{tabular}{|c|c|c|c|c|c|c|c|c|c|c|c|}
\hline \multirow{3}{*}{$\begin{array}{c}\text { Sowing } \\
\text { date }\end{array}$} & \multirow{3}{*}{ Cultivars } & \multicolumn{5}{|c|}{$2012 / 2013$} & \multicolumn{5}{|c|}{$2013 / 2014$} \\
\hline & & \multicolumn{4}{|c|}{$\mathrm{N}$ levels $\left(\mathrm{kg} \mathrm{N} \mathrm{fed}^{-1}\right)$} & \multirow{2}{*}{$\begin{array}{c}\text { Mean } \\
\text { SxG }\end{array}$} & \multicolumn{4}{|c|}{$\mathrm{N}$ levels $\left(\mathrm{kg} \mathrm{N}\right.$ fed $\left.^{-1}\right)$} & \multirow{2}{*}{$\begin{array}{c}\text { Mean } \\
\text { SxG }\end{array}$} \\
\hline & & 0 & 30 & 60 & 90 & & 0 & 30 & 60 & 90 & \\
\hline \multirow{2}{*}{$20 / 11$} & G130 & 68.0 & 71.0 & 73.3 & 72.3 & 71.2 & 69.3 & 71.7 & 73.7 & 74.7 & 72.35 \\
\hline & G135 & 64.7 & 67.3 & 70.7 & 73.0 & 68.9 & 67.0 & 69.3 & 72.0 & 74.3 & 70.65 \\
\hline \multirow{2}{*}{$20 / 12$} & G130 & 65.0 & 67.7 & 69.7 & 70.7 & 68.3 & 65.7 & 68.3 & 70.3 & 72.0 & 69.08 \\
\hline & G135 & 61.0 & 65.0 & 66.7 & 68.7 & 65.4 & 55.0 & 58.0 & 60.3 & 62.0 & 58.83 \\
\hline \multirow{3}{*}{$\begin{array}{c}\text { Mean } \\
\text { NxG }\end{array}$} & G130 & 66.5 & 69.3 & 71.5 & 71.5 & & 66.3 & 68.8 & 71.2 & 73.2 & \\
\hline & G135 & 62.8 & 66.2 & 68.7 & 70.8 & & 62.2 & 64.80 & 67.0 & 68.3 & \\
\hline & Mean $\mathbf{N}$ & 64.7 & 67.8 & 70.1 & 71.2 & & 64.3 & 66.8 & 69.1 & 70.8 & \\
\hline & & \multicolumn{5}{|c|}{$\begin{array}{l}\text { Sowing date }: S \\
\text { Cultivars effect }: S \\
\text { LSD } N=1.356 \\
\text { LSD NxG = NS } \\
\text { LSD SxG =NS } \\
\text { LSD SxNxG =NS }\end{array}$} & \multicolumn{5}{|c|}{$\begin{array}{l}\text { Sowing date : } S \\
\text { Cultivars effect }: S \\
\text { LSD N = 0.760 } \\
\text { LSD NxG = NS } \\
\text { LSD SxG =1.454 } \\
\text { LSD SxNxG =NS }\end{array}$} \\
\hline
\end{tabular}

Table (4): Mean number of days to physiological maturity as influenced by sowing date, nitrogen level, cultivars and their interactions in both seasons.

\begin{tabular}{|c|c|c|c|c|c|c|c|c|c|c|c|}
\hline \multirow{3}{*}{$\begin{array}{c}\text { Sowing } \\
\text { date }\end{array}$} & \multirow{3}{*}{ Cultivars } & \multicolumn{5}{|c|}{$2012 / 2013$} & \multicolumn{5}{|c|}{$2013 / 2014$} \\
\hline & & \multicolumn{4}{|c|}{$\mathrm{N}$ levels $\left(\mathrm{kg} \mathrm{N}^{\mathrm{N}} \mathrm{fed}^{-1}\right)$} & \multirow{2}{*}{$\begin{array}{c}\text { Mean } \\
\text { SxG }\end{array}$} & \multicolumn{4}{|c|}{$\mathrm{N}$ levels $\left(\mathrm{kg} \mathrm{N}^{\mathrm{N}} \mathrm{fed}^{-1}\right)$} & \multirow{2}{*}{$\begin{array}{c}\text { Mean } \\
\text { SxG }\end{array}$} \\
\hline & & $\mathbf{0}$ & 30 & 60 & 90 & & 0 & 30 & 60 & 90 & \\
\hline \multirow{2}{*}{$20 / 11$} & G130 & 100.0 & 107.3 & 108.7 & 113.3 & 107.3 & 102.7 & 105.7 & 108.7 & 112.0 & 107.3 \\
\hline & G135 & 95.7 & 101.7 & 106.0 & 111.0 & 103.6 & 99.7 & 102.3 & 104.3 & 105.7 & 103.0 \\
\hline \multirow{2}{*}{$20 / 12$} & G130 & 98.7 & 103.7 & 107.0 & 109.0 & 104.6 & 103.3 & 106.0 & 107.7 & 110.0 & 106.8 \\
\hline & G135 & 95.0 & 98.3 & 101.7 & 106.7 & 100.4 & 94.3 & 101.3 & 104.0 & 107.0 & 101.7 \\
\hline \multirow{3}{*}{$\begin{array}{l}\text { Mean } \\
\text { NxG }\end{array}$} & G130 & 99.3 & 105.5 & 107.8 & 111.2 & & 103.0 & 105.8 & 108.2 & 111.0 & \\
\hline & G135 & 95.3 & 100.0 & 103.8 & 108.8 & & 97.0 & 101.8 & 104.2 & 106.3 & \\
\hline & Mean N & 97.3 & 102.8 & 105.8 & 110.0 & & 100.0 & 103.8 & 106.2 & 108.7 & \\
\hline & & \multicolumn{5}{|c|}{$\begin{array}{l}\text { Sowing date }: S \\
\text { Cultivars effect }: S \\
\text { LSD N = 1.173 } \\
\text { LSD NxG = NS } \\
\text { LSD SxG = NS } \\
\text { LSD SxNxG = NS }\end{array}$} & \multicolumn{5}{|c|}{$\begin{array}{l}\text { Sowing date }: \mathrm{NS} \\
\text { Cultivars effect }: \mathrm{S} \\
\text { LSD N }=1.062 \\
\text { LSD NxG }=\mathrm{NS} \\
\text { LSD SxG }=\mathrm{NS} \\
\text { LSD SxNxG = 2.125 }\end{array}$} \\
\hline
\end{tabular}

and 108.7days) in both seasons, respectively. Moreover, all interactions affected days to maturity in both seasons. These results are in harmony with those of Mohamed (2009).

\subsubsection{Plant height}

Results presented in Table (5) showed that plant height was significantly affected by sowing date and $\mathrm{N}$ level in the $1^{\text {st }}$ season, while all the studied factors and their interactions had a significant effect in the $2^{\text {nd }}$ season. Sowing on November 20 produced taller plants. This could be due to long life time of the plant which gave a maximum vegetative growth. plant height varied from 
Table (5): Mean plant height $(\mathrm{cm})$ as influenced by sowing date, nitrogen level, cultivars and their interactions in both seasons.

\begin{tabular}{|c|c|c|c|c|c|c|c|c|c|c|c|}
\hline \multirow{3}{*}{$\begin{array}{c}\text { Sowing } \\
\text { date }\end{array}$} & \multirow{3}{*}{ Cultivars } & \multicolumn{5}{|c|}{$2012 / 2013$} & \multicolumn{5}{|c|}{ 2013/2014 } \\
\hline & & \multicolumn{4}{|c|}{$\mathrm{N}$ levels (kg N fed ${ }^{-1}$ ) } & \multirow{2}{*}{$\begin{array}{c}\text { Mean } \\
\text { SxG }\end{array}$} & \multicolumn{4}{|c|}{$\mathrm{N}$ levels (kg N fed ${ }^{-1}$ ) } & \multirow{2}{*}{$\begin{array}{c}\text { Mean } \\
\text { SxG }\end{array}$} \\
\hline & & $\mathbf{0}$ & 30 & 60 & 90 & & $\mathbf{0}$ & 30 & 60 & 90 & \\
\hline \multirow{2}{*}{$20 / 11$} & G130 & 58.0 & 62.0 & 64.3 & 65.7 & 62.5 & 57.7 & 60.0 & 61.0 & 62.0 & 60.2 \\
\hline & G135 & 58.7 & 61.0 & 63.3 & 65.7 & 62.2 & 52.7 & 56.0 & 59.7 & 61.3 & 57.4 \\
\hline \multirow{2}{*}{ 20/12 } & G130 & 57.0 & 59.3 & 61.3 & 60.7 & 59.6 & 57.7 & 58.7 & 60.7 & 62.7 & 60.0 \\
\hline & G135 & 57.0 & 58.7 & 61.0 & 64.3 & 60.3 & 57.3 & 58.7 & 61.0 & 63.0 & 60.0 \\
\hline \multirow{3}{*}{$\begin{array}{c}\text { Mean } \\
\text { NxG }\end{array}$} & G130 & 57.5 & 60.7 & 62.8 & 63.2 & & 57.7 & 59.4 & 60.9 & 62.4 & \\
\hline & G135 & 57.8 & 59.8 & 62.2 & 65.0 & & $\mathbf{5 5 . 0}$ & 57.4 & 60.4 & 62.2 & \\
\hline & Mean N & 57.7 & 60.3 & 62.5 & 64.1 & & 56.4 & 58.4 & 60.6 & 62.3 & \\
\hline & & $\begin{array}{l}\text { Sowi } \\
\text { Culti } \\
\text { LSD } \\
\text { LSD } \\
\text { LSD } \\
\text { LSD }\end{array}$ & $\begin{array}{l}\text { dete } \\
\text { s effe } \\
=\mathbf{2 . 2} \\
\mathbf{G}= \\
\mathbf{G}=1 \\
\mathbf{S x G}\end{array}$ & $\begin{array}{l}\text { NS } \\
\text { SS }\end{array}$ & & & $\begin{array}{l}\text { Sown } \\
\text { Cultiv } \\
\text { LSDD } \\
\text { LSD S } \\
\text { LSD }\end{array}$ & $\begin{array}{r}\text { ate : } \\
\text { effect } \\
0.46 \\
=0 . \\
=1 \\
x G=\end{array}$ & & & \\
\hline
\end{tabular}

57.0 to $65.7 \mathrm{~cm}$ at the $1^{\text {st }}$ season and from 57.3 to 63.0 days at the $2^{\text {nd }}$ season. Giza 130 recorded a maximum plant height in both seasons compared to Giza 135. Plant height was increased by increasing $\mathrm{N}$ levels and this was clear in the $2^{\text {nd }}$ season. The average plant height was $57.7,60.3,62.5$ and 64.1 $\mathrm{cm}$ in the $1^{\text {st }}$ season and 56.4, 58.4, 60.6 and $62.3 \mathrm{~cm}$ in the $2^{\text {nd }}$ season with $0,30,60$ and $90 \mathrm{~kg} \mathrm{~N} \mathrm{fed}{ }^{-1}$, respectively. These results suggested that early sowing with $\mathrm{N}$ fertilizer application might have improved the vegetative growth of the crop. These finding are in agreement with those reported by of Abdur et al. (2010).

\subsubsection{Spike length}

Results presented in Table (6) indicated that different sowing dates, cultivars and $\mathrm{N}$ levels had a significant effect on spike length in both seasons, except for sowing date in the $2^{\text {nd }}$ season. Spike length varied from 3.5 to $6.9 \mathrm{~cm}$ at the $1^{\text {st }}$ season and from 2.9 to $5.4 \mathrm{~cm}$ at the $2^{\text {nd }}$ season. Giza 135 produced the longest spike than that of Giza 130 in the $1^{\text {st }}$ season but Giza 130 gave the longest spike in the $2^{\text {nd }}$ season. The average of Spike length was 4.4, 5.4, 5.9 and $6.3 \mathrm{~cm}$ in the $1^{\text {st }}$ season and 3.4, 4.0, 4.4 and $4.8 \mathrm{~cm}$ in the $2^{\text {nd }}$ season with $0,30,60$ and $90 \mathrm{~kg} \mathrm{~N}$ $\mathrm{fed}^{-1}$, respectively. Application of $90 \mathrm{~kg} \mathrm{~N}$ $\mathrm{fed}^{-1}$ gave the highest spike length (6.3 and $4.8 \mathrm{~cm})$ in the $1^{s t}$ and the $2^{\text {nd }}$ seasons, respectively. On the other hand, all interactions showed insignificant effect with the exception of SxG and SxGxN in the $2^{\text {nd }}$ season. These results are in harmony with those of Mohamed (2009).

\subsection{Yield and its components}

\subsubsection{Number of kernels spike ${ }^{-1}$}

Results in Table (7) revealed that the number of kernels spike ${ }^{-1}$ was significantly ( $p \leq 0.05)$ affected by sowing date, cultivars and $\mathrm{N}$ levels in the $1^{\text {st }}$ season. On the other hand, this effect was by $\mathrm{N}$ level in the $2^{\text {nd }}$ season. All interactions showed insignificant effect with the exception of $\mathrm{GxN}$ and $\mathrm{SxN}$ in the $1^{\text {st }}$ season also $\mathrm{SxG}$ and $\mathrm{SxGxN}$ in the $2^{\text {nd }}$ season. The early sowing date produced higher number of grains spike ${ }^{-1}$. The average of grains spike ${ }^{-1}$ varied from 23.0 to 44.3 in the $1^{\text {st }}$ season and from 19.7 to 34.0 in the $2^{\text {nd }}$ season. This could be attributed to the different genetic systems of the studied barley cultivars. Results showed that barley 
Table (6): Mean spike length $(\mathrm{cm})$ as influenced by sowing date, nitrogen level, cultivars and their interactions in both seasons.

\begin{tabular}{|c|c|c|c|c|c|c|c|c|c|c|c|}
\hline \multirow{3}{*}{$\begin{array}{c}\text { Sowing } \\
\text { date }\end{array}$} & \multirow{3}{*}{ Cultivars } & \multicolumn{5}{|c|}{$2012 / 2013$} & \multicolumn{5}{|c|}{$2013 / 2014$} \\
\hline & & \multicolumn{4}{|c|}{$\mathrm{N}$ levels (kg N fed ${ }^{-1}$ ) } & \multirow{2}{*}{$\begin{array}{c}\text { Mean } \\
\text { SxG }\end{array}$} & \multicolumn{4}{|c|}{$\mathrm{N}$ levels (kg N fed ${ }^{-1}$ ) } & \multirow{2}{*}{$\begin{array}{c}\text { Mean } \\
\text { SxG }\end{array}$} \\
\hline & & $\mathbf{0}$ & 30 & 60 & 90 & & $\mathbf{0}$ & 30 & 60 & 90 & \\
\hline \multirow{2}{*}{ 20/11 } & G130 & 4.3 & 5.3 & 6.0 & 6.4 & 5.5 & 3.9 & 4.5 & 5.0 & 5.4 & 4.7 \\
\hline & G135 & 5.2 & 6.0 & 6.5 & 6.9 & 6.2 & 2.9 & 3.4 & 3.7 & 4.0 & 3.5 \\
\hline \multirow{2}{*}{$20 / 12$} & G130 & 3.5 & 4.6 & 5.1 & 5.5 & 4.7 & 3.3 & 3.6 & 4.0 & 4.3 & 3.8 \\
\hline & G135 & 4.3 & 5.6 & 5.9 & 6.3 & 5.5 & 3.5 & 4.4 & 4.7 & 5.3 & 4.5 \\
\hline \multirow{3}{*}{$\begin{array}{c}\text { Mean } \\
\text { NxG }\end{array}$} & G130 & 3.9 & 4.9 & 5.5 & 5.9 & & 3.6 & 4.0 & 4.5 & 4.9 & \\
\hline & G135 & 4.8 & 5.8 & 6.2 & 6.6 & & 3.2 & 3.9 & 4.2 & 4.7 & \\
\hline & Mean $\quad \mathrm{N}$ & 4.4 & 5.4 & 5.9 & 6.3 & & 3.4 & 4.0 & 4.4 & 4.8 & \\
\hline & & $\begin{array}{l}\text { Sowi } \\
\text { Culti } \\
\text { LSD } \\
\text { LSD } \\
\text { LSD } \\
\text { LSD }\end{array}$ & $\begin{array}{l}\text { date : } \\
\text { s effe } \\
=0.1 \\
G= \\
G= \\
G x G \\
\text { vo }\end{array}$ & & & & $\begin{array}{l}\text { Sowin } \\
\text { Culti } \\
\text { LSD } \\
\text { LSD } \\
\text { LSD } \\
\text { LSD }\end{array}$ & $\begin{array}{r}\text { te }: \\
\text { effec } \\
1.53 \\
= \\
=0 . \\
x G=\end{array}$ & & & \\
\hline
\end{tabular}

Table (7): Mean number of kernels spike ${ }^{-1}$ as influenced by sowing date, nitrogen levels, cultivars and their interactions in both seasons.

\begin{tabular}{|c|c|c|c|c|c|c|c|c|c|c|c|}
\hline \multirow{3}{*}{$\begin{array}{c}\text { Sowing } \\
\text { date }\end{array}$} & \multirow{3}{*}{ Cultivars } & \multicolumn{5}{|c|}{$2012 / 2013$} & \multicolumn{5}{|c|}{$2013 / 2014$} \\
\hline & & \multicolumn{4}{|c|}{$\mathrm{N}$ levels $\left(\mathrm{kg} \mathrm{N}\right.$ fed $\left.^{-1}\right)$} & \multirow{2}{*}{$\begin{array}{c}\text { Mean } \\
\text { SxG }\end{array}$} & \multicolumn{4}{|c|}{$\mathrm{N}$ levels $\left(\mathrm{kg} \mathrm{N}\right.$ fed $\left.^{-1}\right)$} & \multirow{2}{*}{$\begin{array}{c}\text { Mean } \\
\text { SxG }\end{array}$} \\
\hline & & $\mathbf{0}$ & 30 & 60 & 90 & & $\mathbf{0}$ & 30 & 60 & 90 & \\
\hline \multirow{2}{*}{ 20/11 } & G130 & 29.3 & 33.7 & 36.0 & 38.7 & 34.4 & 22.7 & 26.0 & 28.3 & 34.0 & 22.8 \\
\hline & G135 & 31.3 & 37.7 & 42.0 & 44.3 & 38.8 & 18.0 & 20.7 & 22.7 & 25.3 & 26.1 \\
\hline \multirow{2}{*}{$20 / 12$} & G130 & 23.0 & 26.0 & 29.7 & 33.7 & 28.1 & 19.7 & 22.3 & 25.3 & 27.0 & 27.8 \\
\hline & G135 & 25.7 & 30.0 & 33.3 & 38.3 & 31.8 & 22.7 & 24.7 & 27.0 & 30.3 & 21.7 \\
\hline \multirow{3}{*}{$\begin{array}{c}\text { Mean } \\
\text { NxG }\end{array}$} & G130 & 26.2 & 29.8 & 32.8 & 36.2 & & 21.2 & 24.2 & 26.8 & 30.5 & \\
\hline & G135 & 28.5 & 33.8 & 37.7 & 41.3 & & 20.3 & 22.7 & 24.8 & 27.8 & \\
\hline & $\begin{array}{ll}\text { Mean } & \mathbf{N}\end{array}$ & 27.4 & 31.8 & 35.3 & 38.8 & & 20.8 & 23.5 & 25.8 & 29.2 & \\
\hline & & $\begin{array}{l}\text { Sowin } \\
\text { Cultiv } \\
\text { LSD } \\
\text { LSD } \\
\text { LSD } \\
\text { LSD S }\end{array}$ & $\begin{array}{l}\text { date: } \\
\text { rs effe } \\
=1.1 \\
\mathbf{G}= \\
\mathbf{G}= \\
\mathbf{N}= \\
\mathbf{N} \mathbf{G}\end{array}$ & & & & $\begin{array}{l}\text { Sowin } \\
\text { Cultiv } \\
\text { LSD } \\
\text { LSD } \\
\text { LSD S } \\
\text { LSD S }\end{array}$ & $\begin{array}{r}\text { ate : N } \\
\text { effect } \\
0.899 \\
=N \\
=1.3 \\
x G=\end{array}$ & & & \\
\hline
\end{tabular}

cultivars significantly differed in the number of kernels spike ${ }^{-1}$ in both seasons. Giza 135 gave the highest kernels spike $^{-1}$ in the $1^{\text {st }}$ season while, Giza 130 produced the highest value in the $2^{\text {nd }}$ season. The average of number of kernels spike $^{-1}$ was $27.4,31.8$,
35.3 and 38.8 in the $1^{\text {st }}$ season and 20.8 , $23.5,25.8$ and $29.2 \mathrm{~cm}$ in the $2^{\text {nd }}$ season with $0,30,60$ and $90 \mathrm{~kg} \mathrm{~N}$ fed $^{-1}$, respectively. The effect of $\mathrm{N}$ fertilizer levels on kernels spike $^{-1}$ was significant in both seasons. Application of nitrogen at the rate of $90 \mathrm{~kg} \mathrm{~N}$ 
fed $^{-1}$ gave the highest number of kernels spike $^{-1}$ (38.8 and 29.2 g) in the $1^{\text {st }}$ and the $2^{\text {nd }}$ seasons, respectively. These findings are in agreement with those obtained by Turk et al. (2003).

\subsubsection{Spike kernel weight}

Means of spike kernel weight are presented in Table (8). Results indicated that sowing date, cultivars, $\mathrm{N}$ levels and their interactions except $\mathrm{GxN}$ in the $1^{s t}$ season and $\mathrm{SxN}$ in the $2^{\text {nd }}$ season had a significant $(p<0.05)$ effect on the spike kernel weight. Sowing date on the $20^{\text {th }}$ of Nov. produced heavier spike kernels weight than late sowing one. It varied from 0.91 to $1.80 \mathrm{~g}$ in the $1^{\text {st }}$ season and from 0.62 to $1.33 \mathrm{~g}$ in the $2^{\text {nd }}$ season for early and late sowing date, respectively. Giza 130 gave the heaviest spike kernel weight as compared with Giza 135 in both seasons, respectively. The average of number of kernels spike ${ }^{-1}$ was $0.98,1.11,1.23$ and 1.50 in the $1^{\text {st }}$ season and $0.79,0.86,0.89$ and $1.08 \mathrm{~g}$ in the $2^{\text {nd }}$ season with $0,30,60$ and $90 \mathrm{~kg} \mathrm{~N}^{-1} \mathrm{fed}^{-1}$, respectively. Also the results showed that spike kernel weight was significantly increased by increasing nitrogen fertilizer levels in both seasons. Application of nitrogen fertilizer at the rate of $90 \mathrm{~kg} \mathrm{~N}$ $\mathrm{fed}^{-1}$ gave the heaviest spike kernel weight $(1.50$ and $1.08 \mathrm{~g})$ in the $1^{\text {st }}$ and the $2^{\text {nd }}$ seasons, respectively. These results are in agreement with those of Said et al. (2012) and Mohamed (2009).

\subsubsection{0-Kernel weight}

Analysis of data indicated that sowing dates, cultivars, $\mathrm{N}$ levels and their interactions except $\mathrm{SxN}$ and $\mathrm{GxN}$ in the $1^{\text {st }}$ season and $\mathrm{S}$ in the $2^{\text {nd }}$ were significant $(\mathrm{p}<0.05)$ Table (9). Sowing date on $20^{\text {th }}$ Nov. produced heavier grains than late sown one in both seasons. It varied from 27.2 to $44.7 \mathrm{~g}$ in the $1^{\text {st }}$ season and from 23.3 to 35.9 $\mathrm{g}$ in the $2^{\text {nd }}$ season respectively. These results are in agreement with those of Refay (2011) and Said et al. (2012). Giza 130 gave the heaviest 1000-kernal weight as compared with Giza 135 in both seasons, respectively. The average of number of kernels spike $^{-1}$ was 30.6, 34.3, 37.5 and 40.1 $\mathrm{g}$ in the $1^{\text {st }}$ season and 25.1, 27.6, 29.6 and $32.4 \mathrm{~g}$ in the $2^{\text {nd }}$ season with $0,30,60$ and $90 \mathrm{~kg} \mathrm{~N} \mathrm{fed}^{-1}$, respectively. Also, the results showed that 1000-kernal weight significantly increased with nitrogen fertilizer levels in both seasons, and application nitrogen fertilizer at the rate of $90 \mathrm{~kg} \mathrm{~N} \mathrm{fed}^{-1}$ gave the heaviest 1000-kernel weight (40.1 and $32.4 \mathrm{~g})$ in the $1^{\text {st }}$ and the $2^{\text {nd }}$ seasons, respectively. These results are supported with those obtained by Abdur et al. (2010) and Refay (2011).

\subsubsection{Biological yield}

Results presented in Table (10) revealed high significant differences among sowing date, cultivars, $\mathrm{N}$ levels and their interaction in both seasons except $\mathrm{SxG}$ interaction in the $2^{\text {nd }}$ season. It varied from 2.20 to $6.93 \mathrm{t} \mathrm{fed}^{-1}$ in the $1^{\text {st }}$ season and from 2.47 to $6.97 \mathrm{t} \mathrm{fed}^{-1}$ in the $2^{\text {nd }}$ season respectively. On the other hand, all interactions showed significant effect in both seasons. Maximum biological yield was recorded under the early sowing, while minimum biological yield was obtained from late sowing date in the $1^{\text {st }}$ and the $2^{\text {nd }}$ season respectively. The average of Biological yield was 3.00, 3.99, 4.85 and $6.28 \mathrm{t} \mathrm{fed}^{-1}$ in the $1^{\text {st }}$ season and 2.94, 4.07, 4.77 and $6.13 \mathrm{t} \mathrm{fed}^{-1}$ in the $2^{\text {nd }}$ season with $0,30,60$ and $90 \mathrm{~kg} \mathrm{~N}^{-1}$, respectively. Giza 130 gave the highest biological yield as compared with Giza 135 in both seasons, respectively. The results also showed that biological yield was significantly increased as nitrogen fertilizer levels increased in both seasons. The rate of $90 \mathrm{~kg} \mathrm{~N} \mathrm{fed}^{-1}$ gave the highest biological yield (6.28 and $6.13 \mathrm{t} \mathrm{fed}^{-}$ ${ }^{1}$ ) in $1^{\text {st }}$ and $2^{\text {nd }}$ seasons, respectively. These finding are in harmony with those reported by El-Sayed et al (1991), El-Sayed et al (2000) and Mohamed (2009).

\subsubsection{Grain yield}

Table (11) and Figs (1 and 2) showed that sowing date, cultivars and $\mathrm{N}$ levels had a significant effect on grain yield in both seasons, It varied from 6.13 to $19.61 \mathrm{ard} \mathrm{fed}^{-}$ ${ }^{1}$ in the $1^{\text {st }}$ season and from 5.60 to 17.86 ard $\mathrm{fed}^{-1}$ in the $2^{\text {nd }}$ season respectively. On the other hand, all interactions showed significant effect in both seasons. Maximum 


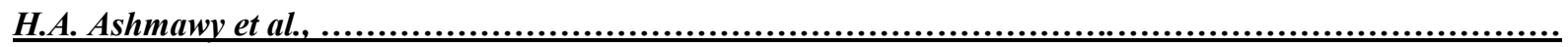

Table (8): Mean spike kernels weight gm as influenced by sowing date, nitrogen level, cultivars and their interactions in both seasons.

\begin{tabular}{|c|c|c|c|c|c|c|c|c|c|c|c|}
\hline \multirow{3}{*}{$\begin{array}{c}\text { Sowing } \\
\text { date }\end{array}$} & \multirow{3}{*}{ Cultivars } & \multicolumn{5}{|c|}{$2012 / 2013$} & \multicolumn{5}{|c|}{$2013 / 2014$} \\
\hline & & \multicolumn{4}{|c|}{$\mathrm{N}$ levels $\left(\mathrm{kg} \mathrm{N}^{\mathrm{N}}\right.$ fed $\left.^{-1}\right)$} & \multirow{2}{*}{$\begin{array}{c}\text { Mean } \\
\text { SxG }\end{array}$} & \multicolumn{4}{|c|}{$\mathrm{N}$ levels $\left(\mathrm{kg} \mathrm{N}^{\mathrm{N}} \mathrm{fed}^{-1}\right)$} & \multirow{2}{*}{$\begin{array}{c}\text { Mean } \\
\text { SxG }\end{array}$} \\
\hline & & 0 & 30 & 60 & 90 & & $\mathbf{0}$ & 30 & 60 & 90 & \\
\hline \multirow{2}{*}{$20 / 11$} & G130 & 0.94 & 1.01 & 1.09 & 1.37 & 1.10 & 0.94 & 0.96 & 1.03 & 1.33 & 1.07 \\
\hline & G135 & 1.09 & 1.43 & 1.60 & 1.80 & 1.48 & 0.62 & 0.65 & 0.67 & 0.73 & 0.67 \\
\hline \multirow{2}{*}{$20 / 12$} & G130 & 0.91 & 0.98 & 1.17 & 1.47 & 1.13 & 0.70 & 0.83 & 0.88 & 0.93 & 0.84 \\
\hline & G135 & 0.96 & 1.01 & 1.06 & 1.33 & 1.09 & 0.92 & 0.96 & 0.98 & 1.30 & 1.04 \\
\hline \multirow{3}{*}{$\begin{array}{c}\text { Mean } \\
\text { NxG }\end{array}$} & G130 & 0.93 & 0.99 & 1.12 & 1.42 & & 0.81 & 0.90 & 0.95 & 1.13 & \\
\hline & G135 & 1.03 & 1.22 & 1.33 & 1.57 & & 0.77 & 0.81 & 0.83 & 1.02 & \\
\hline & Mean N & 0.98 & 1.11 & 1.23 & 1.50 & & 0.79 & 0.86 & 0.89 & 1.08 & \\
\hline & & $\begin{array}{l}\text { Sowin } \\
\text { Cultiv } \\
\text { LSD I } \\
\text { LSD } \\
\text { LSD } \\
\text { LSD }\end{array}$ & $\begin{array}{l}\text { date : } \\
\text { s effe } \\
=0.0 \\
G= \\
G=0 \\
\text { JxG }\end{array}$ & $\begin{array}{l}\mathrm{S} \\
32 \\
.136\end{array}$ & & & $\begin{array}{l}\text { Sowin } \\
\text { Cultiv } \\
\text { LSD 1 } \\
\text { LSD } \\
\text { LSD S } \\
\text { LSD S }\end{array}$ & $\begin{array}{r}\text { te : } \mathrm{S} \\
\text { effect } \\
0.038 \\
=\mathrm{N} \\
=0.0 \\
\mathrm{xG}=\end{array}$ & & & \\
\hline
\end{tabular}

Table (9): Mean weight of 1000-kernel as influenced by sowing date, nitrogen level, cultivars and their interactions in both seasons.

\begin{tabular}{|c|c|c|c|c|c|c|c|c|c|c|c|}
\hline \multirow{3}{*}{$\begin{array}{c}\text { Sowing } \\
\text { date }\end{array}$} & \multirow{3}{*}{ Cultivars } & \multicolumn{5}{|c|}{$2012 / 2013$} & \multicolumn{5}{|c|}{$2013 / 2014$} \\
\hline & & \multicolumn{4}{|c|}{$\mathrm{N}$ levels $\left(\mathrm{kg} \mathrm{N} \mathrm{fed}^{-1}\right)$} & \multirow{2}{*}{$\begin{array}{c}\text { Mean } \\
\text { SxG }\end{array}$} & \multicolumn{4}{|c|}{$\mathbf{N}$ levels $\left(\mathrm{kg} \mathbf{N e d}^{-1}\right)$} & \multirow{2}{*}{$\begin{array}{c}\text { Mean } \\
\text { SxG }\end{array}$} \\
\hline & & $\mathbf{0}$ & 30 & 60 & 90 & & $\mathbf{0}$ & 30 & 60 & 90 & \\
\hline \multirow{2}{*}{$20 / 11$} & G130 & 30.7 & 34.0 & 37.1 & 38.6 & 35.1 & 27.0 & 32.0 & 34.0 & 35.9 & 32.2 \\
\hline & G135 & 34.3 & 38.7 & 42.6 & 44.7 & 40.1 & 23.3 & 24.3 & 25.7 & 27.3 & 25.2 \\
\hline \multirow{2}{*}{$20 / 12$} & G130 & 27.2 & 30.3 & 35.0 & 38.7 & 32.8 & 25.0 & 27.3 & 30.0 & 33.7 & 29.0 \\
\hline & G135 & 29.8 & 33.8 & 35.2 & 38.2 & 34.3 & 25.0 & 26.7 & 28.7 & 32.7 & 28.3 \\
\hline \multirow{3}{*}{$\begin{array}{c}\text { Mean } \\
\text { NxG }\end{array}$} & G130 & 29.0 & 32.2 & 36.1 & 38.6 & & 26.0 & 29.7 & 32.0 & 34.8 & \\
\hline & G135 & 32.1 & 36.3 & 38.9 & 41.5 & & 24.2 & 25.5 & 27.2 & 30.0 & \\
\hline & Mean N & 30.6 & 34.3 & 37.5 & 40.1 & & 25.1 & 27.6 & 29.6 & 32.4 & \\
\hline & & $\begin{array}{l}\text { Sowin } \\
\text { Cultiv } \\
\text { LSD } \\
\text { LSD } \\
\text { LSD } \\
\text { LSD }\end{array}$ & $\begin{array}{l}\text { date }: \\
\text { s effec } \\
=0.74 \\
\text { G }=1 \\
G=1 \\
\text { NxG }=\end{array}$ & $\begin{array}{l}S \\
80 \\
.482\end{array}$ & & & $\begin{array}{l}\text { Sowin } \\
\text { Cultiv } \\
\text { LSD } \\
\text { LSD 1 } \\
\text { LSD S } \\
\text { LSD S }\end{array}$ & $\begin{array}{r}\text { te : } N \\
\text { effect } \\
0.584 \\
=0.8 \\
=2.5 \\
x G=1\end{array}$ & & & \\
\hline
\end{tabular}


Table (10): Mean biological yield ton fed $^{-1}$ as influenced by sowing date, nitrogen level, cultivars and their interactions in both seasons.

\begin{tabular}{|c|c|c|c|c|c|c|c|c|c|c|c|}
\hline \multirow{3}{*}{$\begin{array}{c}\text { Sowing } \\
\text { date }\end{array}$} & \multirow{3}{*}{ Cultivars } & \multicolumn{5}{|c|}{$2012 / 2013$} & \multicolumn{5}{|c|}{$2013 / 2014$} \\
\hline & & \multicolumn{4}{|c|}{$\mathrm{N}$ levels $\left(\mathrm{kg} \mathrm{N}\right.$ fed $\left.^{-1}\right)$} & \multirow{2}{*}{$\begin{array}{c}\text { Mean } \\
\text { SxG }\end{array}$} & \multicolumn{4}{|c|}{$\mathrm{N}$ levels $\left(\mathrm{kg} \mathrm{N}_{\mathrm{fed}}{ }^{-1}\right)$} & \multirow{2}{*}{$\begin{array}{c}\text { Mean } \\
\text { SxG }\end{array}$} \\
\hline & & $\mathbf{0}$ & 30 & 60 & 90 & & $\mathbf{0}$ & 30 & 60 & 90 & \\
\hline \multirow{2}{*}{ 20/11 } & G130 & 3.67 & 4.17 & 5.57 & 6.93 & 5.04 & 3.73 & 4.22 & 5.87 & 6.83 & 5.16 \\
\hline & G135 & 2.40 & 4.27 & 4.80 & 6.77 & 4.56 & 3.00 & 4.30 & 4.83 & 6.97 & 4.78 \\
\hline \multirow{2}{*}{$20 / 12$} & G130 & 3.73 & 4.23 & 5.17 & 6.63 & 4.94 & 2.53 & 3.96 & 4.27 & 5.73 & 4.12 \\
\hline & G135 & 2.20 & 3.30 & 3.63 & 4.80 & 3.49 & 2.47 & 3.80 & 4.10 & 5.20 & 3.89 \\
\hline \multirow{3}{*}{$\begin{array}{c}\text { Mean } \\
\text { NxG }\end{array}$} & G130 & 3.70 & 4.20 & 5.37 & 6.78 & & 3.13 & 4.09 & 5.07 & 6.17 & \\
\hline & G135 & 2.30 & 3.78 & 4.33 & 5.78 & & 2.73 & 4.05 & 4.46 & 6.08 & \\
\hline & Mean $\mathbf{N}$ & 3.00 & 3.99 & 4.85 & 6.28 & & 2.94 & 4.07 & 4.77 & 6.13 & \\
\hline & & $\begin{array}{l}\text { Sowi } \\
\text { Culti } \\
\text { LSD } \\
\text { LSD } \\
\text { LSD } \\
\text { LSD }\end{array}$ & $\begin{array}{l}\text { date: } \\
\text { rs effe } \\
=0.5 \\
\text { G }= \\
G= \\
\text { NxG }\end{array}$ & $\begin{array}{l}\mathrm{S} \\
793 \\
99 \\
.122\end{array}$ & & & $\begin{array}{l}\text { Sowin } \\
\text { Culti } \\
\text { LSD } \\
\text { LSD } \\
\text { LSD } \\
\text { LSD }\end{array}$ & $\begin{array}{r}\text { ate : } \mathrm{S} \\
\text { effect } \\
0.406 \\
=0 . \\
=\mathrm{N} \\
\mathbf{x G}=\end{array}$ & & & \\
\hline
\end{tabular}

Table (11): Mean gran yield ( $\operatorname{ard~fed~}^{-1}$ ) as influenced by sowing date, nitrogen level, cultivars and their interactions in both seasons.

\begin{tabular}{|c|c|c|c|c|c|c|c|c|c|c|c|}
\hline \multirow{3}{*}{$\begin{array}{c}\text { Sowing } \\
\text { date }\end{array}$} & \multirow{3}{*}{ Cultivars } & \multicolumn{5}{|c|}{$2012 / 2013$} & \multicolumn{5}{|c|}{$2013 / 2014$} \\
\hline & & \multicolumn{4}{|c|}{$\mathrm{N}$ levels $\left(\mathrm{kg} \mathbf{N}\right.$ fed $\left.^{-1}\right)$} & \multirow{2}{*}{$\begin{array}{c}\text { Mean } \\
\text { SxG }\end{array}$} & \multicolumn{4}{|c|}{$\mathrm{N}$ levels $\left(\mathrm{kg} \mathbf{N}\right.$ fed $\left.^{-1}\right)$} & \multirow{2}{*}{$\begin{array}{c}\text { Mean } \\
\text { SxG }\end{array}$} \\
\hline & & $\mathbf{0}$ & 30 & 60 & 90 & & $\mathbf{0}$ & 30 & 60 & 90 & \\
\hline \multirow{2}{*}{$20 / 11$} & G130 & 8.47 & 10.57 & 17.09 & 19.61 & 13.94 & 10.96 & 11.94 & 17.16 & 17.86 & 14.50 \\
\hline & G135 & 6.13 & 11.94 & 13.76 & 16.11 & 11.97 & 8.33 & 13.10 & 12.92 & 15.02 & 12.36 \\
\hline \multirow{2}{*}{$20 / 12$} & G130 & 6.41 & 8.05 & 10.85 & 13.62 & 9.73 & 5.85 & 8.02 & 10.57 & 14.67 & 9.77 \\
\hline & G135 & 6.93 & 7.39 & 8.75 & 12.08 & 8.79 & 5.60 & 7.07 & 8.61 & 10.43 & 7.95 \\
\hline \multirow{3}{*}{$\begin{array}{c}\text { Mean } \\
\text { NxG }\end{array}$} & G130 & 7.46 & 9.31 & 13.97 & 16.63 & & 8.40 & 9.98 & 13.83 & 16.28 & \\
\hline & G135 & 6.55 & 9.66 & 11.27 & 14.11 & & 6.97 & 8.33 & 10.78 & 12.71 & \\
\hline & Mean N & 7.00 & 9.49 & 12.61 & 15.37 & & 7.70 & 9.17 & 12.32 & 14.50 & \\
\hline & & $\begin{array}{l}\text { Sowin } \\
\text { Cultiv } \\
\text { LSD I } \\
\text { LSD I } \\
\text { LSD } \\
\text { LSD }\end{array}$ & $\begin{array}{l}\text { date : } \\
\text { s effec } \\
=0.19 \\
\text { G = } \\
G=0 \\
\text { NxG }=\end{array}$ & $\begin{array}{l}: S \\
: S 6 \\
143 \\
0.391\end{array}$ & & & $\begin{array}{l}\text { Sowing } \\
\text { Cultiv } \\
\text { LSD N } \\
\text { LSD N } \\
\text { LSD S } \\
\text { LSD S }\end{array}$ & $\begin{array}{r}\text { ate : } S \\
\text { effect } \\
0.125 \\
=0.1 \\
=0.1 \\
x G=c\end{array}$ & $\begin{array}{l}S \\
7 \\
4 \\
250\end{array}$ & & \\
\hline
\end{tabular}




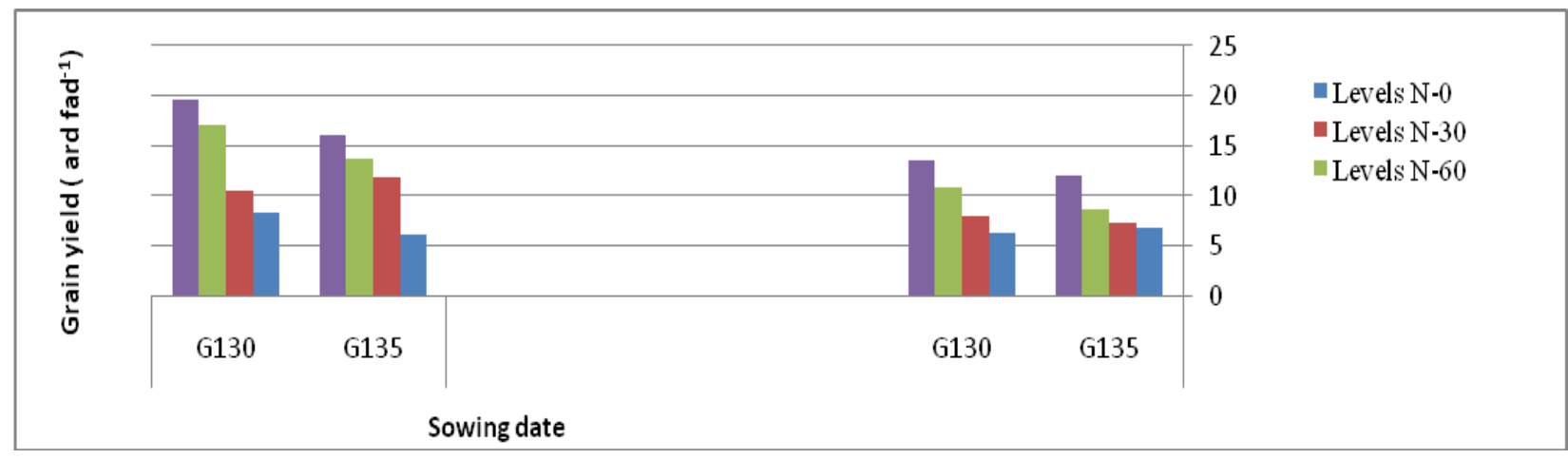

Fig. (1): Mean of grain yield $\left(\operatorname{ard~fed~}^{-1}\right.$ ) as influenced by sowing date, nitrogen levels and cultivars in 2012/2013.

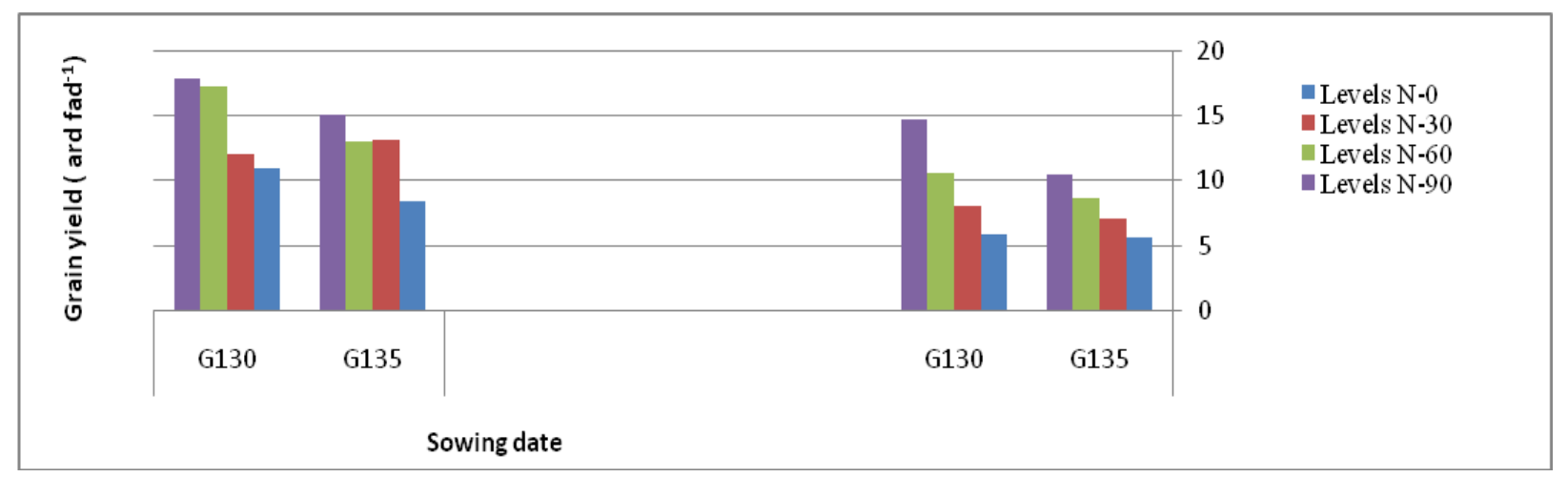

Fig. (2): Mean of grain yield ( $\operatorname{ard~fed}^{-1}$ ) as influenced by sowing date, nitrogen levels and cultivars in 2013/2014.

grain yield was recorded from the $20^{\text {th }}$ of Nov planting date, while minimum grain yield was obtained from the $20^{\text {th }}$ of Dec. in both seasons respectively. These results are in agreement with those of Yesmin et al. (2014).Giza 130 gave the highest grain yield as compared with Giza 135 in both seasons, respectively. The average of grain yield was $7.00,9.49,12.61$ and 15.37 ard fed $^{-1}$ in the $1^{\text {st }}$ season and 7.70, 9.17, 12.32 and 14.50 ard $\mathrm{fed}^{-1}$ in the $2^{\text {nd }}$ season with $0,30,60$ and $90 \mathrm{~kg} \mathrm{~N}$ fed $^{-1}$, respectively. Increasing nitrogen fertilizer had a significant effect on grain yield in both seasons, and application of nitrogen fertilizer at the rate of $90 \mathrm{~kg} \mathrm{fed}^{-1}$ gave the highest grain yield (15.37 and 14.50 ard fed $^{-1}$ ) in the $1^{\text {st }}$ and the $2^{\text {nd }}$ seasons, respectively. This observation agreed with that recorded by Refay (2011) and Said et al. (2012).

\subsubsection{Straw yield (SY)}

Results presented in Table (12) revealed significant differences among sowing date, cultivars and $\mathrm{N}$ levels in both seasons, except for cultivars in the $2^{\text {nd }}$ season insignificant effect on straw yield. It varied from 1.37 to $5.00 \mathrm{t} \mathrm{fed}^{-1}$ in the $1^{\text {st }}$ season and from 1.79 to $5.17 \mathrm{t} \mathrm{fed}^{-1}$ in the $2^{\text {nd }}$ season respectively. On the other hand, all interactions showed significant effect with the exception of $\mathrm{SxG}$ in both seasons. Maximum SY was recorded from $20^{\text {th }}$ Nov. sowing date in the $1^{\text {st }}$ and the $2^{\text {nd }}$ seasons, respectively, while minimum SY was obtained from $20^{\text {th }}$ Dec. in the $1^{\text {st }}$ and the $2^{\text {nd }}$ seasons, respectively. Giza 130 gave the 
Table (12): Mean straw yield (ton fed $^{-1}$ ) as influenced by sowing date, nitrogen level, cultivars and their interactions in both seasons.

\begin{tabular}{|c|c|c|c|c|c|c|c|c|c|c|c|}
\hline \multirow{3}{*}{$\begin{array}{c}\text { Sowing } \\
\text { date }\end{array}$} & \multirow{3}{*}{ Cultivars } & \multicolumn{5}{|c|}{$2012 / 2013$} & \multicolumn{5}{|c|}{$2013 / 2014$} \\
\hline & & \multicolumn{4}{|c|}{$\mathrm{N}$ levels $\left(\mathrm{kg} \mathrm{N}\right.$ fed $\left.^{-1}\right)$} & \multirow{2}{*}{$\begin{array}{c}\text { Mean } \\
\text { SxG }\end{array}$} & \multicolumn{4}{|c|}{$\mathrm{N}$ levels $\left(\mathrm{kg} \mathrm{N} \mathrm{fed}^{-1}\right)$} & \multirow{2}{*}{$\begin{array}{c}\text { Mean } \\
\text { SxG }\end{array}$} \\
\hline & & $\mathbf{0}$ & 30 & 60 & 90 & & 0 & 30 & 60 & 90 & \\
\hline \multirow{2}{*}{ 20/11 } & G130 & 2.65 & 2.90 & 3.52 & 4.58 & 3.41 & 2.42 & 2.78 & 3.81 & 4.69 & 3.43 \\
\hline & G135 & 1.66 & 2.84 & 3.15 & 4.83 & 3.12 & 2.00 & 2.73 & 3.28 & 5.17 & 3.30 \\
\hline \multirow{2}{*}{$20 / 12$} & G130 & 2.97 & 3.27 & 3.86 & 5.00 & 3.78 & 1.83 & 3.00 & 3.00 & 2.71 & 2.64 \\
\hline & G135 & 1.37 & 2.42 & 2.58 & 3.35 & 2.43 & 1.79 & 2.95 & 3.07 & 3.95 & 2.94 \\
\hline \multirow{3}{*}{$\begin{array}{c}\text { Mean } \\
\text { NxG }\end{array}$} & G130 & 2.81 & 3.08 & 3.69 & 4.79 & & 2.13 & 2.89 & 3.41 & 4.22 & \\
\hline & G135 & 1.52 & 2.63 & 2.97 & 4.10 & & 1.90 & 3.05 & 3.17 & 4.56 & \\
\hline & Mean N & 2.16 & 2.86 & 3.33 & 4.23 & & 2.01 & 2.97 & 3.29 & 4.39 & \\
\hline & & $\begin{array}{l}\text { Sowi } \\
\text { Culti } \\
\text { LSD } \\
\text { LSD } \\
\text { LSD } \\
\text { LSD }\end{array}$ & $\begin{array}{l}\text { date } \\
\text { rs effe } \\
=0.5 \\
\mathbf{G}= \\
G= \\
\mathbf{N x G}\end{array}$ & $\begin{array}{l}: S \\
798 \\
1.128\end{array}$ & & & $\begin{array}{l}\text { Sowin } \\
\text { Culti } \\
\text { LSD } \\
\text { LSD } \\
\text { LSD } \\
\text { LSD }\end{array}$ & $\begin{array}{r}\text { ate }: 1 \\
\text { effect } \\
0.36 \\
=0 \\
=N \\
x G=\end{array}$ & & & \\
\hline
\end{tabular}

highest SY as compared with Giza 135 in $1^{\text {st }}$ season. The average of Straw yield was $2.16,2.86,3.33$ and $4.23 \mathrm{t} \mathrm{fed}^{-1}$ in the $1^{\text {st }}$ season and 2.01, 2.97, 3.29 and $4.39 \mathrm{t} \mathrm{fed}^{-1}$ in the $2^{\text {nd }}$ season with $0,30,60$ and $90 \mathrm{~kg} \mathrm{~N}$ $\mathrm{fed}^{-1}$, respectively. Also the results showed that SY was significantly affected by nitrogen fertilizer levels in both seasons, and application of nitrogen fertilizer at the rate of $90 \mathrm{~kg} \mathrm{fed}^{-1}$ gave the highest SY (4.23 and $\left.4.39 \mathrm{t} \mathrm{fed}^{-1}\right)$ in the $1^{\text {st }}$ and the $2^{\text {nd }}$ seasons, respectively. These results are in harmony with those reported by El-Sayed et al. (1991), Mohamed (2009) and Said et al. (2012).

\subsubsection{Harvest index (HI)}

Harvest index (HI) of barley was significantly affected by sowing date in both seasons Table (13). Maximum HI \% was recorded from $20^{\text {th }}$ Nov. sowing date in both seasons, respectively, while minimum $\mathrm{HI} \%$ was obtained from $20^{\text {th }}$ Dec. in 2012/13 and 2013/14 seasons, respectively. It varied from 20.6 to $37.8 \%$ in the $1^{\text {st }}$ season and from 22.3 to $36.5 \%$ in the $2^{\text {nd }}$ season respectively. Results showed that there was a significant difference between the two barley cultivars for $\mathrm{HI}$ in both seasons. Giza 130 gave HI of as compared with Giza 135 in the $1^{\text {st }}$ and the $2^{\text {nd }}$ seasons, respectively. The average of harvest index was 29.3, 28.4, 31.4 and $29.4 \%$ in the $1^{\text {st }}$ season and 31.4 , $27.0,30.9$ and $28.4 \%$ in the $2^{\text {nd }}$ season with $0,30,60$ and $90 \mathrm{~kg} \mathrm{~N}$ fed $^{-1}$, respectively. Giza 130 gave the highest HI as compared with Giza 135 in the $1^{\text {st }}$ and the $2^{\text {nd }}$ seasons, respectively. Also the results showed that HI was significantly increased with increasing nitrogen fertilizer level in both seasons, and application of nitrogen fertilizer at the rate of $60 \mathrm{~kg} \mathrm{~N} \mathrm{fed}^{-1}$ gave the highest HI $(31.4$ and $30.9 \%$ ) in the $1^{\text {st }}$ and the $2^{\text {nd }}$ seasons, respectively. These results are in agreement with those obtained by Alam et al. (2007), Mohamed (2009) and Said et al. (2012).

\section{Conclusion}

From the previous results, it could be concluded that barley Giza 130 is performing well, when it is planted at $20^{\text {th }}$ Nov with $\mathrm{N}$ fertilizer level of $90 \mathrm{~kg} \mathrm{~N}^{\mathrm{N}} \mathrm{fed}^{-1}$ to achieve the highest grain yield under the New Valley conditions. 


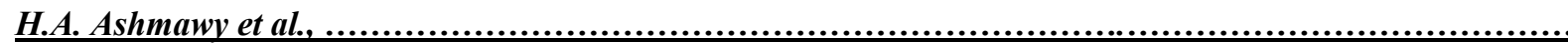

Table (13): Mean harvest index as influenced by sowing date, nitrogen level, cultivars and their interaction in both seasons.

\begin{tabular}{|c|c|c|c|c|c|c|c|c|c|c|c|}
\hline \multirow{3}{*}{$\begin{array}{c}\text { Sowing } \\
\text { date }\end{array}$} & \multirow{3}{*}{ Cultivars } & \multicolumn{5}{|c|}{$2012 / 2013$} & \multicolumn{5}{|c|}{$2013 / 2014$} \\
\hline & & \multicolumn{4}{|c|}{ N levels (kg N fed ${ }^{-1}$ ) } & \multirow{2}{*}{$\begin{array}{c}\text { Mean } \\
\text { SxG }\end{array}$} & \multicolumn{4}{|c|}{$\mathrm{N}$ levels $\left(\mathrm{kg} \mathbf{N}\right.$ fed $\left.^{-1}\right)$} & \multirow{2}{*}{$\begin{array}{c}\text { Mean } \\
\text { SxG }\end{array}$} \\
\hline & & $\mathbf{0}$ & 30 & 60 & 90 & & 0 & 30 & 60 & 90 & \\
\hline \multirow{2}{*}{$20 / 11$} & G130 & 27.7 & 30.4 & 36.8 & 33.9 & 33.2 & 35.2 & 34.0 & 35.1 & 31.4 & 33.9 \\
\hline & G135 & 30.7 & 33.6 & 34.4 & 28.6 & 31.8 & 33.3 & 36.5 & 32.0 & 25.9 & 31.9 \\
\hline \multirow{2}{*}{$20 / 12$} & G130 & 20.6 & 22.8 & 25.2 & 24.6 & 23.3 & 27.7 & 24.3 & 29.7 & 30.7 & 28.9 \\
\hline & G135 & 37.8 & 26.8 & 28.9 & 30.2 & 30.9 & 27.3 & 22.3 & 25.2 & 24.1 & 24.7 \\
\hline \multirow{3}{*}{$\begin{array}{c}\text { Mean } \\
\text { NxG }\end{array}$} & G130 & 24.2 & 26.6 & 31.2 & 29.3 & & 32.2 & 29.3 & 32.8 & 31.7 & \\
\hline & G135 & 34.3 & 30.2 & 31.7 & 29.4 & & 30.6 & 24.7 & 29.0 & 25.1 & \\
\hline & Mean $\quad$ N & 29.3 & 28.4 & 31.4 & 29.4 & & 31.4 & 27.0 & 30.9 & 28.4 & \\
\hline & & \multicolumn{5}{|c|}{$\begin{array}{l}\text { Sowing date }: S \\
\text { Cultivars effect }: S \\
\text { LSD } N=2.20 \\
\text { LSD NxG = 3.8 } \\
\text { LSD SxG = NS } \\
\text { LSD SxNxG }=\mathbf{5 . 3}\end{array}$} & \multicolumn{5}{|c|}{$\begin{array}{l}\text { Sowing date : } \mathrm{S} \\
\text { Cultivars effect }: \mathrm{S} \\
\text { LSD N }=1.2 \\
\text { LSD NxG = 1.7 } \\
\text { LSD SxG }=\mathrm{NS} \\
\text { LSD SxNxG }=\mathbf{2 . 4}\end{array}$} \\
\hline
\end{tabular}

\section{REFERENCES}

Abdur R., Khan U. R., Marwat S. K. and Ali Z. (2010). Response of barley to sowing date and fertilizer application under rainfed condition. World J. Agric. Sci. 6(5): 480-484.

Alam M. Z., Haider S.A. and Paul N.K. (2007). Yield and yield components of barley (Hordeum vulgare L.) cultivars in relation to nitrogen fertilizer. J. App. Sci. Res., 3(10): 1022-1026.

Blum A.(1985). Breeding crop varieties for stress environments. Review Plant Sci, 2: 199-288.

El-Sayed A. A., Noaman M. M. and El-Rayes A. (1991). Water requirement of barley in sandy soil. 1. Effect of flood irrigation frequency and nitrogen fertilizer rate on growth and yield attributes. Egypt. J. Appi. Sci., 6:210-2018.

El-Sayed A. A., Abo El-Enein R. A., Shalab E.E., Shalan M. A. and Said M. A. (2000). Response of barley fertilizer with $\mathrm{N}$ and $\mathrm{P}$ application under newly reclaimed areas in Egypt. Proc. of $3^{\text {rd }}$ International Crop Science Congress., 1722 August 2000, Hamburg, Germany.

Hayes P. M., Castro A., Cedillo L. M., Corey A., Henson C., Jones B.L., Kling J., Matus D., Rossi I. and Sato K. (2003). Genetic diversity for quantitatively inherited agronomic and malting quality traits. Elsevier Science Publishers, Amsterdam, the Netherlands Chapter10 pages.

Hefni E.H.M. (1976). Effect of phosphorus and nitrogen fertilizer on the yield and agronomic characters of barley. Annals. Agric. Sci. Moshtohor, 6: 23-31.

Lewis C. F. and Christiansen M. N. (1981). Breeding plants for stress environments. Plant Breeding, 11: 151-178.

Misra B. N., Singh K. N. and Shastry L.V.S. (1980). Nutrient and irrigation requirements of 2-row barley. Indian J. Agron., 25(3): 410-414.

Modhej A. (2011). Effects of nitrogen rates on grain yield and grain growth of spring wheat genotypes under post-anthesis heat stress conditions. Advances in Environmental Biology, 5(9): 25702578.

Mohamed A. A. B. (2009). Effect of irrigation intervals and nitrogen fertilization on some new barley cultivars under New Valley conditions. Ph.D. Thesis, Fac. Agric., Al-Azhar Univ., Cairo, Egypt.

Orabi A., Abdel-Hamid M. and Assad F. A. (1998). Effect of irrigation intervals and nitrogen fertilization on barley under 